\section{NOVOS HORIZONTES NO DIÁLOGO ENTRE PSICANÁLISE E MEDICINA}

\section{Um novo lance de dados: psicanálise e medicina na contemporaneidade.} Organizado por Joel Birman, Isabel Fortes e Simone Perelson. Rio de Janeiro: Cia de Freud, 2010. 263 p.

\section{Silvia Alexim Nunes}

Psicanalista, membro do Espaço Brasileiro de Estudos Psicanalíticos, doutora em Saúde Coletiva IMS/Uerj.

Um novo lance de dados: psicanálise e medicina na contemporaneidade, coletânea organizada por Joel Birman, Isabel Fortes e Simone Perelson e produzida pelo Programa de Pós-Graduação em Teoria Psicanalítica da UFRJ, é um livro que, como o título indica, coloca em jogo diversas peças de um caleidoscópio extremamente complexo: as relações entre psicanálise e medicina. Seus diversos autores não são jogadores inexperientes, e sim professores e pesquisadores que vêm há muitos anos procurando elaborar essa intricada rede de relações a partir de perspectivas singulares. O resultado desse trabalho fica evidenciado nesse livro estimulante, que aborda temáticas atualíssimas.

A coletânea reaviva uma reflexão em torno de questões fundamentais, pertinentes à psicanálise e à medicina, fugindo da querela antiga, e muitas vezes estéril, em torno de saber quem detém a verdade sobre as subjetividades, suas formas de viver e de sofrer. Nas palavras dos organizadores, a proposta foi: "trazer para o centro do debate questões que se colocam hoje como fundamentais no diálogo entre psicanálise e medicina”.

Tal diálogo foi, desde o início, marcado por conflitos, assimilações acríticas e disputas de poder que pouco contribuíram para o aprofundamento dos problemas colocados para a própria clínica. Nascida no bojo da medicina, a partir da clínica da histeria, a psicanálise se confrontou, desde o início, com os sintomas corporais e com uma racionalidade médica que, calcada na anatomoclínica, tentava dar conta dessa produção sintomática. Realizando a crítica dessa medicina, Freud colocou no primeiro plano da constituição da subjetividade as dimensões da linguagem, da pulsão e do fantasma, estabelecendo uma ruptura com o paradigma médico, e inaugurando um novo campo de saber.

À tensão estabelecida entre esses dois campos seguiu-se uma solução de compromisso na qual a medicina manteria seu domínio sobre o corpo, legando o psiquismo à psicanálise. Solução que acabou por reeditar a divisão corpo e mente que marcou a modernidade obscurecendo a concepção inaugural de Freud de um psiquismo fundado sobre o corpo. Foi ainda ineficiente, pois as formas contemporâneas de sofrimento físico e psíquico não cessam de denunciar o equívoco dessa partição. 
Se de outros campos de conhecimento como a filosofia, as ciências sociais e a saúde coletiva, as relações entre psicanálise e medicina têm sido bastante problematizadas, nos campos psicanalítico e médico, o que mais se observa é a permanência de uma disputa quase sempre infértil. É no vácuo aberto por essa querela que o presente livro vem se instalar propondo uma reflexão rigorosa e criativa sobre problemas que se apresentam hoje como cruciais tanto para a psicanálise quanto para a medicina.

Abrindo a coletânea, Joel Birman, por meio de uma arqueologia primorosa, procura traçar as linhas de continuidade e descontinuidade existentes entre psicanálise e medicina. Sublinhando que, se a interlocução de Freud com a medicina foi marcada por uma crítica sistemática aos pressupostos científicos do saber médico, sua pesquisa não esteve imune a alguns desses pressupostos, que marcaram seu percurso.

Tania Coelho dos Santos e Jésus Santiago propõem que, a partir dos avanços do aparato biomédico, o não reconhecimento da singularidade do sujeito em jogo no sintoma se intensifica, com consequências clínicas importantes. Não por acaso os ditos 'novos sintomas' estão ligados às patologias do excesso ou da falta no campo da satisfação pulsional, tais como anorexia, bulimia, compulsões e depressões.

Isabel Fortes procura interrogar o aumento da incidência dos casos de anorexia nas últimas décadas. Para isso, destaca o lugar central que a dimensão do corpo ocupa na cultura contemporânea, propondo que na origem dos sintomas corporais que assolam a clínica atual está uma descarga pulsional, sem tradução psíquica, a demandar novas reflexões não só teóricas, mas também sobre o ofício do psicanalista.
Dois artigos tratam da questão da dor enquanto sintoma sine materia. Márcia Aran e Raquel Alcides propõem que o surgimento de uma clínica da dor, que entendem como uma experiência de excesso, recoloca o desafio de integrar os saberes médico e psicanalítico, pois a dor coloca em xeque a dicotomia mente e corpo, a desconsideração da subjetividade de quem adoece e uma clínica calcada em evidências. Já Marta Rezende Cardoso e Patrícia Paraboni concebem a dor física crônica como derivada de uma experiência de luto na qual a dor substitui o objeto perdido, quando esta perda é psiquicamente irrepresentável. Ao mesmo tempo, a dor crônica revela-se como um apelo ao outro e como reivindicação de cuidado.

Priscila Magalhães e Regina Neri, a partir de uma experiência em grupos Balint/Paideia, destacam a importância da construção de um espaço coletivo de elaboração que permita aos profissionais de saúde ressignificarem a angústia resultante do confronto com os limites da tecnologia biomédica, com frequência vivida de forma solitária e como fracasso pessoal.

Júlio Vertzman, Regina Herzog e Teresa Pinheiro abordam a relação psicanálise e psiquiatria questionando se os psicanalistas devem desprezar as categorias diagnósticas psiquiátricas. Partindo da hipótese de que a psiquiatria não cria doenças, mas apenas reconhece um apelo dando a ele um destino, tomaram o diagnóstico de fobia social, procurando avaliar sua pertinência, sua singularidade e as condições de sua produção.

Uma reflexão sobre as implicações das novas tecnologias reprodutivas para a psicanálise é matéria de dois instigantes artigos. Simone Perelson questiona certo olhar psicanalítico que tende a priorizar uma perspectiva negativa sobre essas tecnologias segundo a qual o ato de procriar 
passaria do campo fértil do desejo ao da demanda insaciável. Aprofundando a reflexão sobre o tema, afirma a importância das novas vias que se abrem para a psicanálise.

Já Maria do Carmo Borges de Souza e Marisa Decat de Moura apontam que ao abrir múltiplas possibilidades de invenção de novas formas de parentalidade e de criação de laços sociais, a reprodução assistida produz também novas normas de vida. Nesse cenário, a psicanálise torna-se uma experiência fundamental a possibilitar a elaboração psíquica dessas novas normas.

Os três artigos que completam o livro discutem a ascensão e o lugar ocupado pelo paradigma biológico nos discursos científicos contemporâneos, e a correlata tendência a conceber os indivíduos e suas diferentes formas de vida a partir de pressupostos biológicos, numa visão determinista e reducionista da condição humana.

Christian Hoffmann debate a atual escalada de poder do discurso naturalista questionando as implicações de uma ciência sem sujeito do conhecimento sobre as subjetividades humanas e sobre o sujeito da psicanálise. Assinala a urgência de repensar a articulação da psicanálise com a ciência face essa evolução rumo à naturalização do espírito. Ieda Tucherman analisa as condições que possibilitaram a primazia do discurso biológico na ciência contemporânea e algumas consequências do destaque que tem a biologia hoje, na medida em que, extrapolando seus limites, ganha força como uma ciência que se propõe a dizer a verdade sobre o humano e, com isso, atuar no campo da regulação da vida. Por fim, Fernanda Costa-Moura aponta o lugar ímpar da psicanálise em um contexto no qual o paradigma biológico norteia as concepções psiquiátricas e psi- cológicas. Problematizando alguns efeitos dessa perspectiva naturalista, adverte que o que concerne aos psicanalistas nesse quadro é, não apenas debater se os males do sujeito correspondem ou não às disfunções e carências que lhes são associadas, mas também discriminar as consequências que tais apreensões acarretam e quais operações avalizam.

A densidade das análises e a importância das questões levantadas pelos autores fazem do instigante Um novo lance de dados: psicanálise e medicina na contemporaneidade uma leitura enriquecedora para psicanalistas, decerto, mas também para médicos e demais profissionais do campo "psi" ao relançar os dados, abrem novas perspectivas para um diálogo cada vez mais necessário e oportuno.

Silvia Alexim Nunes

silviaalexim@uol.com.br 